\title{
Meso-Cenozoic Paleotopographies and Paleolandscapes in the Deseado Massif (Santa Cruz Province, Argentina)
}

\author{
F. Bétard, J.P. Peulvast, Jorge Rabassa, and Emilia Y. Aguilera
}

\begin{abstract}
The Deseado Massif is the southernmost part of a continent, outside of Antarctica, where Gondwana Landscapes may be observed and investigated. This chapter presents preliminary observations and field data about the Gondwana Landscapes of this cratonic area of Southern Argentina, one of the most remote, isolated, and less populated places on Earth. Under extreme cold-arid climate conditions, the region presents very scarce vegetation cover, which further enables the geomorphological observations. Remnants of planation surfaces of undisputable Late Mesozoic age, developed on Jurassic volcanic units and covered by Late Cretaceous and Paleogene sedimentary rocks, are exposed along tens of thousands square kilometers of this cratonic unit. In those remote times, the climate of this portion of Patagonia was very wet and warm, allowing the development of extensive chemical weathering.
\end{abstract}

Keywords Gondwana • Argentina • Santa Cruz • Paleosurfaces • Denudation rates

\footnotetext{
F. Bétard $(\square)$

Université Paris-Diderot, Sorbonne Paris Cité, UMR CNRS 8586 PRODIG, Paris, France

e-mail: francois.betard@univ-paris-diderot.fr

J.P. Peulvast

Université Paris-Sorbonne, UFR Géographie et Aménagement, Paris, France

J. Rabassa

Laboratorio de Geomorfología y Cuaternario, CADIC-CONICET, Ushuaia, Tierra del Fuego, Argentina

Universidad Nacional de Tierra del Fuego, Ushuaia, Tierra del Fuego, Argentina

e-mail: jrabassa@gmail.com

E.Y. Aguilera

Facultad de Ciencias Naturales y Museo, Universidad Nacional de La Plata (UNLP), Calles 122 y 60, 1900-La Plata, Argentina

DAIS (Dirección de Aplicación de Imágenes Satelitarias), Calle $7 \mathrm{~N}^{\circ} 1267-2^{\circ} \mathrm{P}$,

1900-La Plata, Argentina

e-mail: eaguilera@ fcnym.unlp.edu.ar
} 


\section{Introduction}

Paleolandforms and paleosurfaces are powerful indicators of long-term landscape evolution in various settings, particularly when studied in combination with stratigraphy or basin analysis (e.g., Widdowson 1997; Peulvast and Claudino Sales 2004; Demoulin et al. 2005; Lidmar-Bergström et al. 2013). Such paleotopographies might give evidence of former environments and landscapes, or paleolandscapes, as well as indications on uplift and erosional histories at various geological timescales (e.g., Peulvast et al. 2008; Bétard 2010). Studies of pre-Cenozoic paleolandforms and Gondwana paleolandscapes have been developed in several areas of Argentina (e.g., Carignano et al. 1999; Demoulin et al. 2005; Aguilera and Rabassa 2010; Rabassa 2010; Rabassa et al. 2010, 2014). In southern Extra-Andean Patagonia where Gondwana paleolandscapes were briefly mentioned by Rabassa et al. (1996, 2010), no detailed paleogeomorphological studies have been developed so far.

This chapter focuses on the Deseado Massif, a large platform area and volcanic province located in Southern Patagonia (Santa Cruz province, Argentina), in the foreland region of the Patagonian Andes. Based on the preliminary results of an extensive field survey achieved in March 2011, this chapter aims to provide a qualitative and quantitative insight into long-term landscape development during the Mesozoic and Cenozoic in the Deseado region. To achieve this, we propose a morphostratigraphic analysis of the regional landscape based on crosscutting relations between paleosurfaces, volcano-sedimentary stratigraphy, and continental paleoweathering.

In situ analyses and sampling of the alteration mantles developed on the Jurassic volcanics were performed for X-ray diffraction studies.

Owing to its richness in paleolandforms and stratigraphic markers of various types and ages, this region affords good opportunities for quantifying the magnitude of long-term uplift and denudation since the breakup of Gondwana, in a context of volcanic rifted margin located at the foreland region of an active orogen.

\section{Study Area: Topography and Geological Setting}

The Deseado Massif is located in Southern Patagonia (Santa Cruz province), separated from the Northern Patagonian Massif by the San Jorge Gulf Basin and from the Southern Patagonian and Fuegian Andes by the Austral Basin (De Giusto et al. 1980; Márquez et al. 2002; Andreis 2002a, b; Giacosa et al. 2002; Haller 2002; Panza and Haller 2002; Panza and Franchi 2002; Malumián 2002; Nullo and Combina 2002; Rabassa et al. 2010; see also the geological map of the province of Santa Cruz, Panza et al. 2003, and references cited in these papers). It constitutes the foreland region of the Patagonian Andes between $46^{\circ}$ and $49^{\circ} \mathrm{S}$ latitude, and also belongs to the low-elevation rifted margin of Eastern Argentina bordering the Atlantic Ocean (Cavallotto et al. 2011). The main topographic features of the Deseado Massif are that of a very large tableland region, with general small local relief, located between 0 and 1,335 m a.s.l. (Fig. 1). All the topographic profiles on 


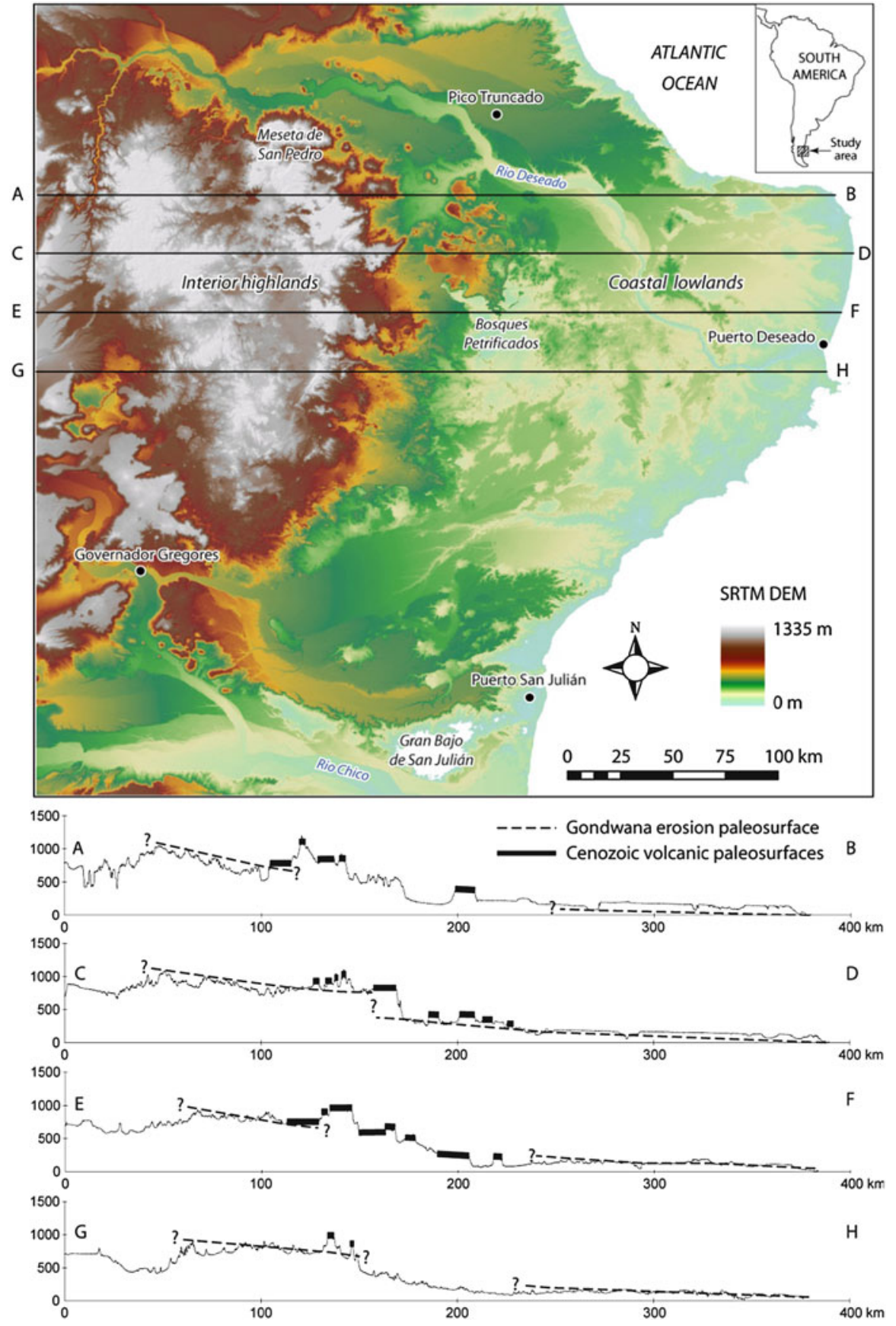

Fig. 1 Topography of the Deseado Massif (derived from SRTM data, version 04). Lettered crosssectional lines refer to the four topographic profiles represented below 
Fig. 1 outline the treads of two main topographic levels: the lower plain or coastal lowland between 0 and $400 \mathrm{~m}$ a.s.l., gently sloping seaward up to the coastline, and a highly dissected plain, or interior highlands, between 600 and 1,100 $\mathrm{m}$ a.s.1., without well-defined slope. Residual bedrock (inselbergs, bornhardts, and tors) and volcanic landforms (necks, buttes, and mesas) are scattered across the plains and plateaus at various altitudes. Higher local relief is found at the contact between the two main topographic levels, 150-200 km from the coast, where it defines the contours of an irregular, locally stepped, high escarpment delimiting the belt of the interior highlands (Fig. 1).

Geologically, the Deseado Massif belongs to a large platform area dominated by Middle-Late Jurassic silicic volcanic rocks (Guido et al. 2004; Fig. 2). Only isolated, small outcrops of Proterozoic-Paleozoic low-grade metamorphic rocks (schists, phyllites, and quartzites), locally intruded by granitoids, are found in the east-central part of this volcanic-dominated geological province (Río Deseado Complex and La Modesta Formation). Overlying these igneous-metamorphic basement rocks is a Permian-Triassic Gondwana siliciclastic cover sequence (La Golondrina, La Juanita, and El Tranquilo formations) which was deposited in a rift basin during an initial extensional phase, followed by block faulting and the development of halfgrabens occupied by lakes and deltas (Homovc and Constantini 2001; Echavarría et al. 2005).

All along the Mesozoic, the tectonic and structural evolution of the Deseado Massif was related to the breakup of Gondwana and the opening of the southern Atlantic Ocean, on one side, and to the subduction process initiated on the western margin of southern South America, on the other side (Echavarría et al. 2005; Giacosa et al. 2010). In the back-arc setting of the Andean subduction zone, established as early as the Middle Jurassic, intense extensional tectonics was accompanied by fissure volcanism and lava flows of the Bajo Pobre Formation and, in the MiddleLate Jurassic, by more acidic volcanism that resulted in a large ignimbrite plateau of pyroclastic flows, laminated tuffs, and megabreccias of rhyolitic composition. These last volcanic and volcaniclastic rocks belong to the Chon Aike and La Matilde formations of the Bahía Laura Group (de Barrio 1989; Guido et al. 2004). The extensional regime which lead to the separation of the American and African continents resulted in the opening of small basins where clastic sediments accumulated from the Late Jurassic to the Late Cretaceous (Bajo Grande and Baqueró formations).

Several marine incursions occurred during the Tertiary, especially in the Early Paleocene (Salamanca Formation) and in the Late Oligocene-Early Miocene (Monte León Formation) (Malumián and Náñez 2011). Finally, during the Tertiary and Quaternary, olivine-rich basalt flows and tuffs were deposited over large areas of the Deseado Massif (Gorring et al. 1997) and today form dissected plateau remnants (mesas and buttes) at various elevations in the landscape. This is also the time of deposition of the "Rodados Patagónicos," or the "Patagonian Shingle Formation" as they were named by Darwin (1842), i.e., immense gravel accumulations of fluvial or glaciofluvial origin formed at various levels since the Late Miocene, between 


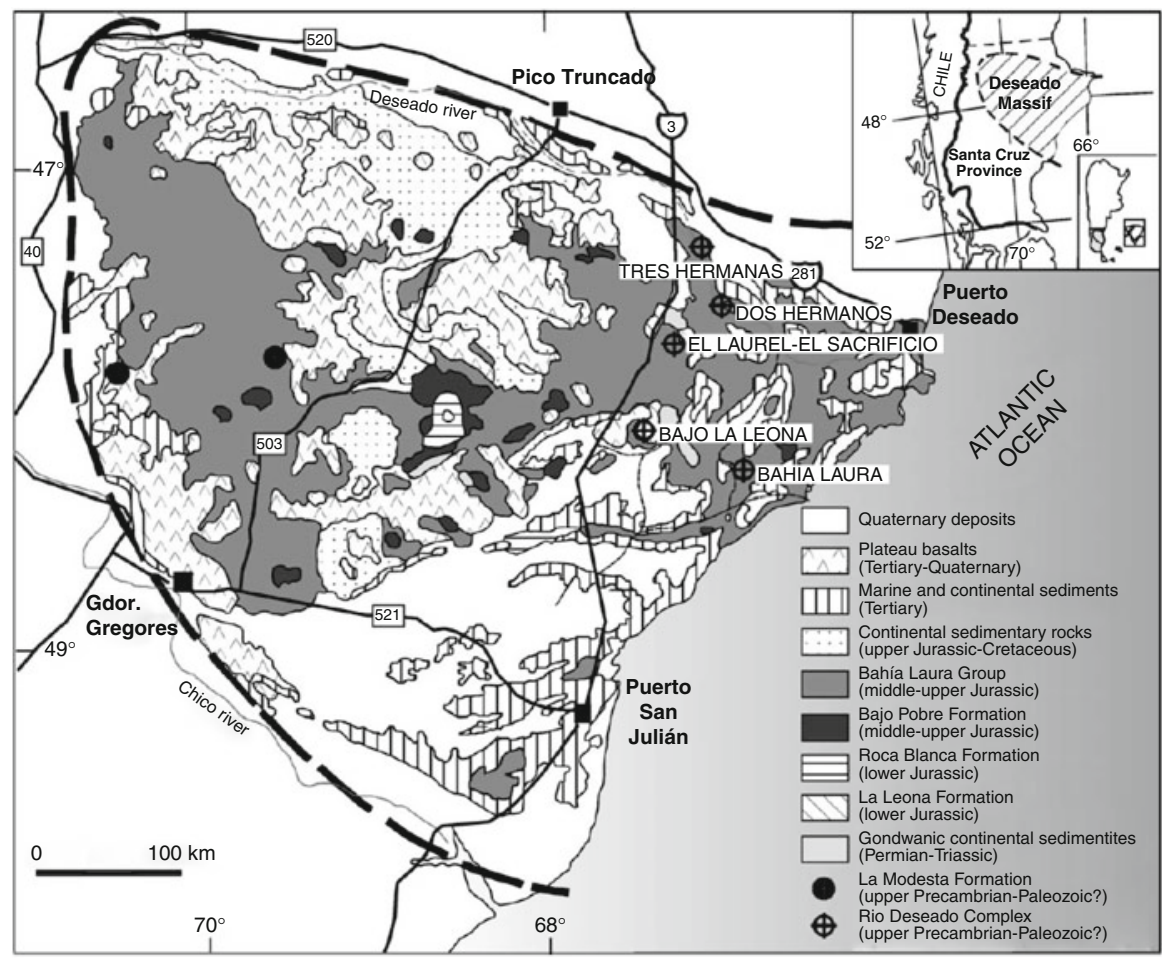

Fig. 2 Simplified geological map of the Deseado Massif (From Guido et al. 2004)

the Andean piedmont and the coast under the control of climatic, glacio-eustatic, and tectonic factors (Fidalgo and Riggi 1965, 1970; Martínez and Kutschker 2011). Most of these units are arranged in stepped systems of mesas, plateaus, and terraces. These surfaces appear widely excavated by wide and shallow valleys originating in the Andes and by multitudes of closed depressions of hectometric to plurikilometric scale, which were formed at all levels, down to $-107 \mathrm{~m}$ for the deepest of them (Gran Bajo de San Julián), by hydro-eolian processes in the semiarid to arid conditions that have prevailed for 14-16 Ma (Blisniuk et al. 2005).

\section{Conceptual and Methodological Remarks}

This chapter is partly based upon the idea that ancient, inactive, or inherited landforms may survive in the landscapes over long periods and that their "age" implies minimal change by denudation processes since their creation (Ollier 1991; Summerfield et al. 1999). It also takes into account the following conceptual 
and methodological remarks which may help establishing a distinction between paleolandforms and transient parts of the geomorphological landscape and to obtain dates for these older generations.

In platform areas as well as in other structural contexts, the most precise ages are obtained on original structural landforms (Peulvast and Vanney 2001), among which endogenic landforms (lava flows and other volcanic constructions, coseismic scarps, etc.) are the most easily dated (Widdowson 1997). Corresponding to specific geological dynamics, they were formed during very short events (earthquake, volcanic eruption, meteorite impact) or sequences of processes (e.g., faulting or folding) that can be dated by relative or absolute methods. The original landforms have the same age as the corresponding structure or the ultimate stage of its formation. In favorable conditions, the age of the simplest of these landforms (volcanic cones, lava flows) may be also deduced from their state of preservation (Peulvast and Vanney 2001).

Among the sets of exogenic or erosion landforms, those of regional to continental scale, with large lateral extent, are the most prone to the presence of well-identified paleolandforms (Widdowson 1997). Their age is less well defined (Peulvast et al. 2009). At first glance, it corresponds to the period when they ceased to evolve. However, various difficulties must be kept in mind in any attempt to date erosion paleosurfaces. For example, the age of a given landform can differ from one part to another (e.g., between the distal and proximal parts of a pediment). Among other conditions, some structural landforms may be created by differential erosion after dissection of a planation surface or through exhumation of buried landscapes. Their age is well known when they relate to a well-dated generation of cyclic landforms or to a climatic sequence (e.g., the structural landforms of glacial origin identified in east Greenland: Peulvast and Vanney 2001). Therefore, inherited or fossil structural landforms (e.g., the paleo-hogbacks of southern Gaspésie, Quebec, still partly sealed by Visean conglomerates: Peulvast et al. 1996) give the best contribution to landform dating and geomorphic reconstructions. Some morphogenetic events which create new landforms may be easily identified thanks to stratigraphic markers with a well-known geometry and age. Primitive structural surfaces or aggradation surfaces corresponding to the ultimate stages of a sedimentary sequence are also useful, if well dated. They may be deformed without being immediately eroded, especially if the deformations correspond to faulting or regional vertical movements.

Initially flat and subhorizontal surfaces, especially planation surfaces, are considered to be the most convenient landmarks to reconstruct the local or regional tectonic and geomorphic history, provided that they are well identified, related with a former base level, and dated (Calvet and Gunnell 2008; Japsen et al. 2009). When well accomplished, planation processes have roughly the same obliterating effects ("resurfacing") on older topographies as aggradation processes. The problem most often encountered with these landforms (pediments, peneplains, pediplains, etchplains) concerns their age (Watchman and Twidale 2002), since most exposed landscapes are often subject to continued modification through dynamic factors and variation in rates controlled by climatic and tectonic environment (Widdowson 1997). This age may be found if a surface is preserved within a stratigraphy 
(unconformity), by dating the rocks immediately above and below, but in most cases, exposed surfaces prevail and only a maximum age is yielded by the bedrock upon which they developed. Unconformable sediment and characteristic weathering formations (i.e., saprolites, ferricretes, calcretes) may help dating planation surfaces or differentiated landscapes (Godard et al. 2001; Vasconcelos and Conroy 2003; Watchman and Twidale 2002). However, such dating is delicate because superficial formations are not always correlative of the planation process, which can be older. Moreover, formations which could be dated by radiochronological methods, as the extensive laterite covers in tropical regions, undergo a continuous geochemical evolution. They cannot be considered as closed systems and stable markers (Gunnell 2003; Nahon 2003), and some of them appear to be dependent on a later, slow incision of low-relief paleosurfaces (laterites: Thomas 1994). Finally, identification of synchronous remnants throughout a vast area is the most favorable case for evaluating tectonic deformations on a given period. Identification of diachronous surfaces or stepped sets of surfaces gives also clues on vertical movements and cyclic or noncyclic types of geomorphic evolution.

Although some authors assume that planation surfaces may be simultaneously developed at different altitudes in the same region in relation with separate base levels (African Surface of southern Africa: Partridge and Maud 1987), stepped systems of undeformed surfaces are generally considered as presenting a chronological meaning (Lageat and Robb 1984; Klein 1997). Elements of various ages and origins often coexist in apparently uniform topographies (Peulvast and Claudino Sales 2005). Uncertainties remain about their age, initial, terminal, before burying or dissection, or since exhumation (Dumont 1991). They often are diachronic, particularly if they result from scarp retreat. The residuals and scarps that bound them may correspond to lithological controls, without chronological meaning. Some surfaces cannot be dated since they are constantly reworked in the conditions of acyclic regime or slow degradation (Klein 1997). Possibly difficult on unequally resistant rocks, such as those which form the Jurassic volcanic sequence of the Deseado Massif, their preservation is better where factors of resistance are present (hard bedrock, hard residual cover deposits or saprolites such as laterites, silcretes, or bauxites) and in regions where vertical movements prevail over orogenic movements: this is the case of the Deseado Massif.

\section{Results: Identification and Reconstruction of Paleosurfaces}

Using the above-described criteria, several paleosurfaces of different natures were identified throughout the Deseado region:

1. Erosion paleosurfaces, the master of which is regionally represented by the extensive Gondwana paleosurface of Late Jurassic to Early Cretaceous age

2. Volcanic paleosurfaces of various ages, which were constructed as a direct result of basaltic lavas flow eruptions during the Tertiary and Quaternary 
3. Sedimentary paleosurfaces corresponding to large gravel deposits of Neogene age, called "Rodados Patagónicos" ("Patagonian Shingle Formation"), mainly developed in distal position on the dissected platform, forming an extended Andean piedmont down to the coast

\section{The Gondwana (Late Jurassic-Early Cretaceous) Erosion Paleosurface}

In the Deseado Massif, the so-called Gondwana paleosurface (Rabassa et al. 2010) is the erosion surface that bevels the Middle-Late Jurassic volcanic rocks of the Bahía Laura Group. This surface is unconformably covered by the Cretaceous sediments of the Bajo Grande and Baqueró formations, indicating a Late JurassicEarly Cretaceous age for the shaping of this erosional topography. Such Gondwana paleolandscapes were already mentioned in the Deseado Massif by Rabassa et al. (1996, 2010), who cited extensive erosion surfaces developed on Jurassic volcanics and volcaniclastics of the Chon Aike Formation and other units of the Bahía Laura Group.

Buried or exhumed elements of the Gondwana paleosurface were identified at various elevations in the landscape, in places where remnants of unconformable Neocomian to Aptian sediments were preserved or freshly exhumed. In the western highlands of the Deseado Massif, this surface is uplifted to more than $800 \mathrm{~m}$ a.s.1., where it records a general eastward slope (Fig. 1), although it is locally irregular due to younger volcanic processes (high volcanic necks such as the Cerros Madre e Hija; Fig. 3). To the NW of the "Bosques Petrificados" area (i.e., the National Monument of the Petrified Forests), it is locally downfaulted and buried by a large thickness of Cretaceous sediments, in half-grabens and small basins formed during the opening of the southern Atlantic Ocean in the Late Mesozoic. In the lower plain to the east, wider remnants of the Gondwana paleosurface were identified at low elevations, freshly exhumed or still buried by shallow thicknesses of Cretaceous and Tertiary sediments; at that place paleo-inselbergs, tors, and bornhardts shaped into Jurassic volcanic rocks regularly outcrop from the sedimentary cover (Fig. 4). A reconstruction of the paleosurface geometry in the coastal lowlands indicates the same eastward tilting as in the interior highlands, even if the downwarping appears much less pronounced in that area (Fig. 1).

Partly dissected or degraded, this surface displays numerous depressions, some of which will distinct from more recent depressions of hydro-eolian or other origin. They are interpreted as etch basins, carved between low-relief rock outcrops (tors and bornhardts, including necks and dykes), into irregularly weathered and kaolinized igneous basement rocks (Figs. 1 and 5). This general physiognomy of the bedrock surface topography of the Gondwana paleosurface makes it well recognizable in the regional landscape. The main question arises on the origin of the rock alteration often found at the surface (Fig. 5). 


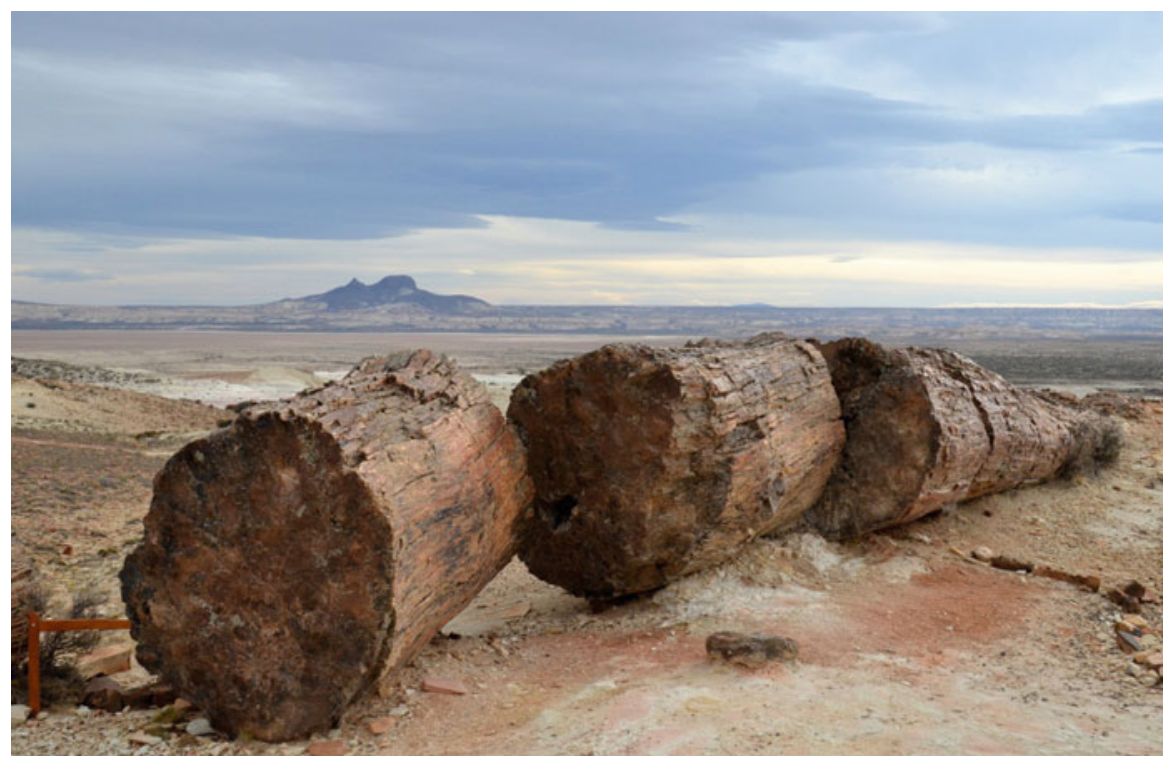

Fig. 3 Cerros Madre e Hija, seen from Bosques Petrificados. Note the silicified trunks of Araucariaceae at the foreground, partly exhumed from Jurassic ignimbrites (LaMatilde Formation) (Photo: J-P. Peulvast)

Weathering products represented by laterite superficial formations have been identified. In those areas where the alteration of the rocky block is very intense, mineral transformation bands are observed, which extend deeply into the rockforming alteration mantles. In these mantles, sectors of varying color such as reddish, brownish, greenish, yellowish, and whitish are suggesting mineralogical and textural compositional changes. In this paleo-weathered surface, the in situ morphological description was completed and sampling was performed on residual deposits, detecting changes in the composition and fabric of the rocks, as gradation from massive to clastic stages, ferruginous crusts, and other mineralogical transformations such as neo-formed clays. By means of X-ray diffractometry performed on seven samples considered as representative of the different field-recognized zones, kaolinite, illite, halloysite, smectite, and quartz were identified (Aguilera et al. 2012) (Figs. 6 and 7).

The existence of residual products as a result of deep weathering suggests that they have been formed under intense regional weathering under wet-tropical climates sometime between the Late Jurassic and the Early Cretaceous, which were the dominant conditions in the Deseado Massif in these periods, as it has been shown by paleoclimatic studies (Aguilera et al. 2012).

The existence of residual deposits due to deep chemical weathering in tropical climates was already recognized by Cravero and Domínguez (1992, and references therein), who described kaolin deposits in Santa Cruz, at the southern portion of 


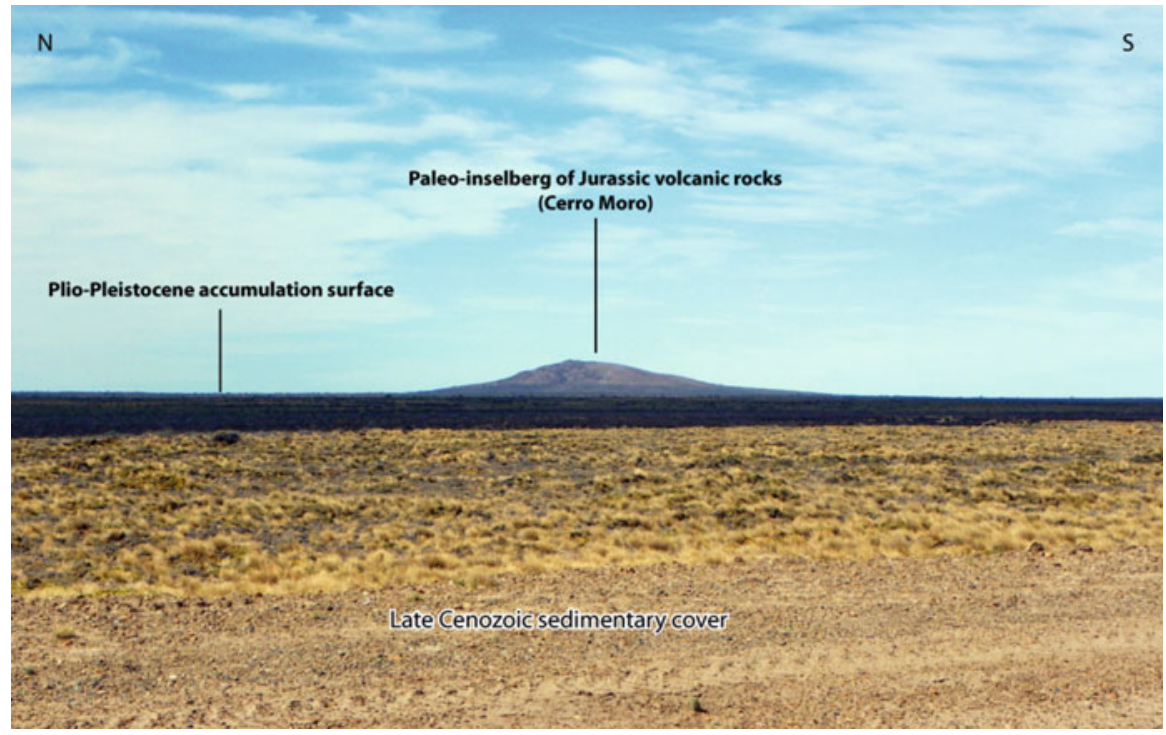

Fig. 4 The Cerro Moro, a paleo-inselberg of Jurassic volcanic rocks (Chon Aike Formation) outcropping from the Late Cenozoic sedimentary cover (Photo: F. Bétard)

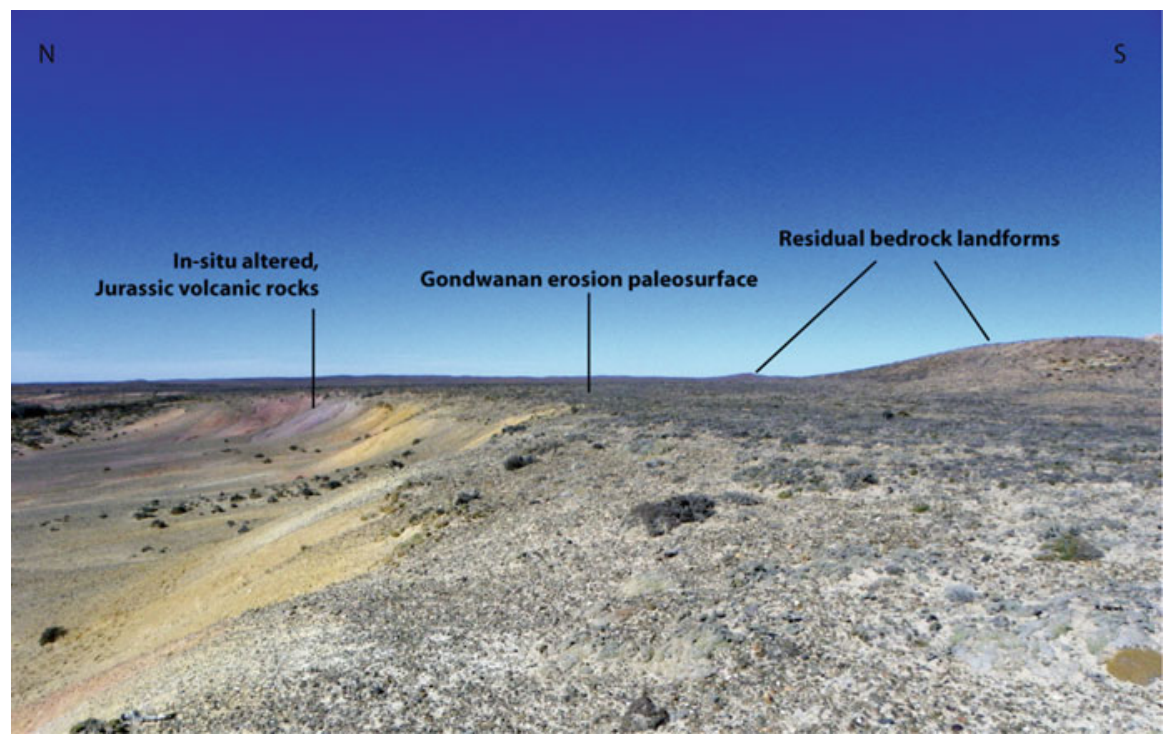

Fig. 5 Superficial morphology of the Gondwana paleosurface, displaying in situ altered Jurassic volcanic rocks in the plane of the irregular paleotopography (Photo: F. Bétard) 


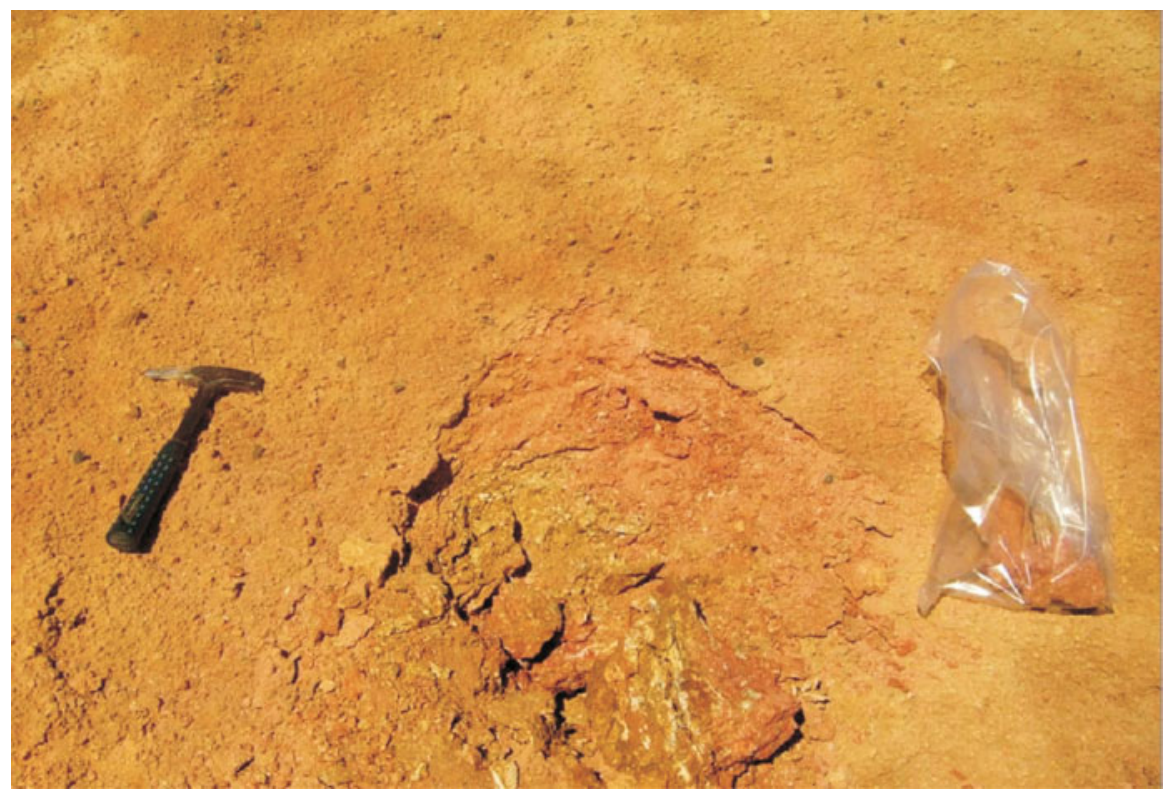

Fig. 6 Remnants of a saprolite mantle over Jurassic volcanic and pyroclastic rocks

the Deseado Massif. These kaolin-bearing units are of fluvial origin, developed within the Baqueró Formation (Middle to Late Cretaceous) over Middle Jurassic ash-flows (Chon Aike Formation) to Early Cretaceous ashfall tuffs (Bajo Grande Formation). This implies that the volcanic units would have been previously altered to kaolinite by deep chemical alteration. Therefore, the authors suggested that kaolin was formed by regional, chemical weathering under humid tropical climates in the Late Jurassic to the Early Cretaceous, being these the dominant environments on the Deseado Massif in those times. Afterwards, when the climate changed towards warm, temperate conditions (113-88 Ma; Nullo and Combina 2011), the weathering products were removed by subaerial fluvial processes to the accumulation areas in the Middle to Late Cretaceous. Nevertheless, previous or synchronous hydrothermal alteration of the igneous rocks cannot be excluded, in a regional context where volcanism was closely followed in time and space by widespread hydrothermal activity and vein formation (Giacosa et al. 2010; Guido and Campbell 2011, 2012).

The existence of younger erosion paleosurfaces is suspected in the region, as advocated by some authors (De Giusto et al. 1980; Rabassa et al. 2010). Highlighting the angular unconformity between the Bajo Grande Formation (Neocomian) and the Baqueró Formation (Aptian; Giacosa et al. 2010), preserved elements of an exhumed sub-Aptian paleosurface were locally identified in the landscape (Fig. 8). It might correspond to a local element of the probably diachronic Gondwana paleosurface, or to a distinct generation of planation surface. The possibility of younger, extensive erosion paleosurfaces, Mesozoic or Cenozoic in age, should be investigated further. 

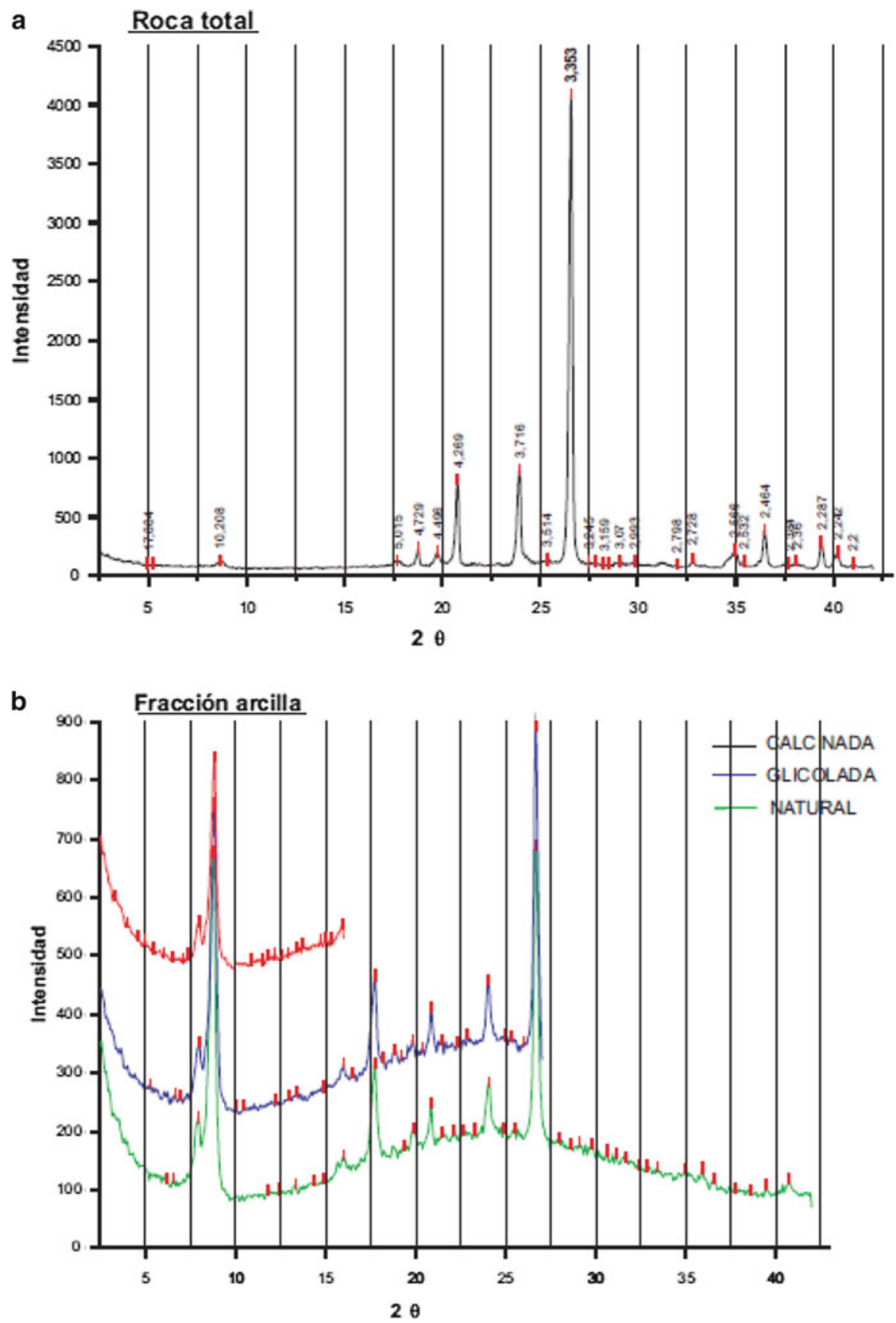

Fig. 7 X-ray diffractometry of total rock (a) and clay fraction (b), on seven samples considered as representative of the different zones identified in the field, in which kaolinite, illite, halloysite, smectite, and quartz are recognized 


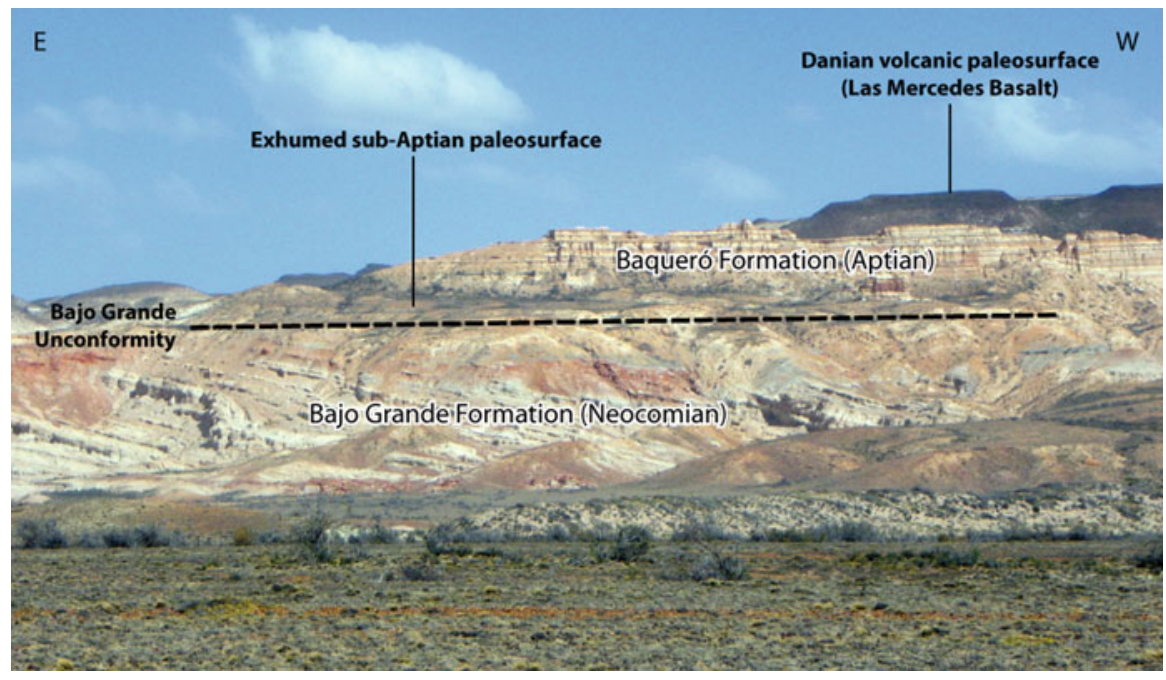

Fig. 8 Angular unconformity between the Bajo Grande Formation (Neocomian) and the Baqueró Formation (Aptian), with exhumed elements of a sub-Aptian paleosurface at the Bajo Grande area (Photo: F. Bétard)

\section{Cenozoic Volcanic Paleosurfaces}

Volcanically generated surfaces of various ages are ubiquitous in the Deseado region, where intense phases of volcanic activity have taken place since the Mesozoic. The volcanic paleosurfaces are currently represented as flat surfaces or plateau remnants which were originally created as a result of fluid basaltic eruptions in the region all along the Cenozoic. Two main generations of Cenozoic volcanic paleosurfaces may be distinguished in the present-day landscape:

1. Paleogene flat-lying and smooth volcanic surfaces, corresponding to the earliest basalt flows occurring since the breakup of Gondwana. In the region, Paleogene and later basalts mainly occur as generally well-preserved flows of melanocratic olivine basalts and basanites. The oldest of these lava flows is the Las Mercedes Basalt, dating from 64 to $63 \mathrm{Ma}$ (Early-Middle Danian: Panza and Franchi 2002) (Fig. 8). The other main Paleogene lava flows are regionally represented by the Cerro del Doce Basalt, dating from between 60 and $40 \mathrm{Ma}$, and the Alma Gaucha Basalt, ranging from 30 to $23 \mathrm{Ma}$ (Panza and Franchi 2002).

2. Neogene volcanic structural surfaces or mesas, corresponding to tholeiitic plateau lavas covered by less voluminous alkaline post-plateau flows, in relation to the opening of an asthenospheric "slab window" associated to ridge collision at the Chile Triple Junction (Gorring et al. 1997). Often intact but locally deeply dissected and reduced to narrow buttes and mesas, especially where thin layers overlay weakly resistant rocks (Fig. 9), these volcanic surfaces are locally topped 


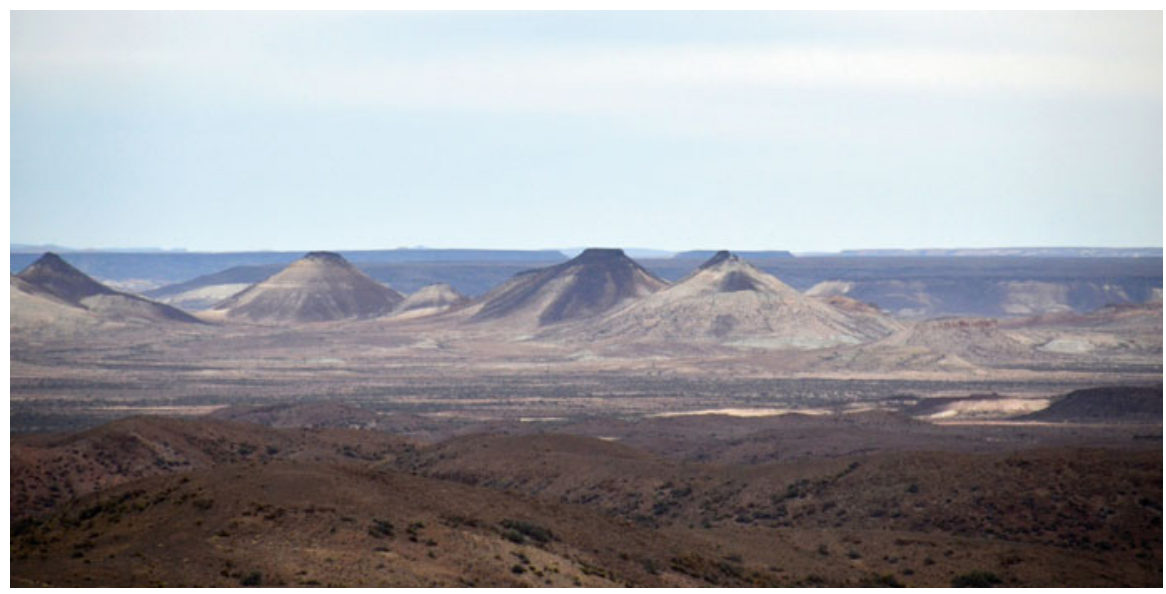

Fig. 9 "Las Pirámides" (SE of "Bosques Petrificados"): dissected Pliocene-Pleistocene basalt flow (La Angelita Formation) overlying weakly resistant, Jurassic volcaniclastic rocks (La Matilde Formation) (Photo: J-P. Peulvast)

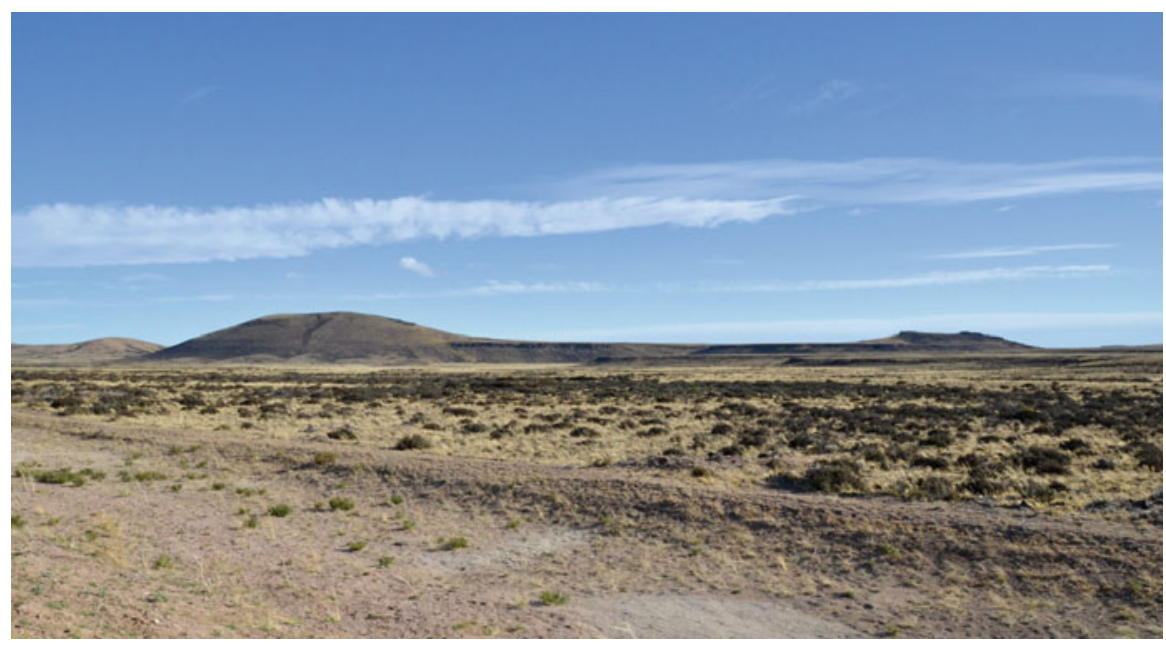

Fig. 10 Cerro Lavatorio: Pliocene-Pleistocene cinder cone and basalt flow (La Angelita Formation), NE of Gobernador Gregores (Photo: J-P. Peulvast)

by Pleistocene cinder cones (Fig. 10). In the study area, the main plateau lavas range between 12 and $7 \mathrm{Ma}$ in the western part of the back-arc region and between 5 and $2 \mathrm{Ma}$ in the eastern part of the Deseado Massif (Gorring et al. 1997). The Pliocene-Pleistocene post-plateau basalts have ages from 3.4 to $0.125 \mathrm{Ma}$ (Gorring et al. 2003), mainly corresponding to the basaltic lava flows of the La Angelita Formation. 


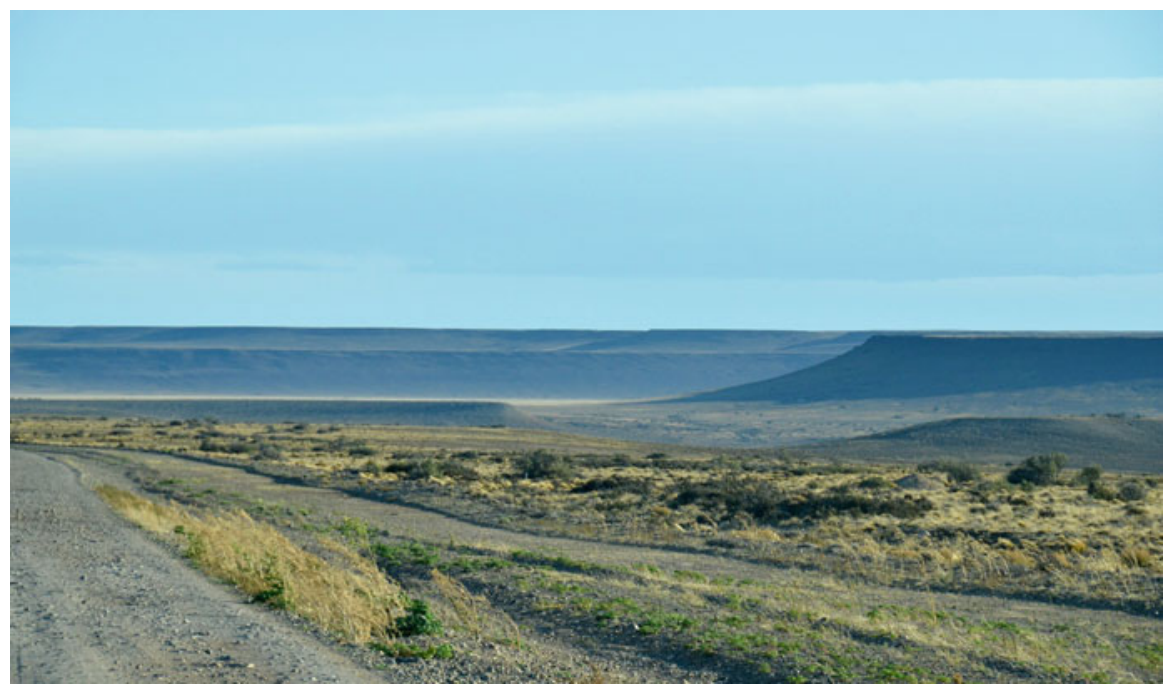

Fig. 11 Stepped or inset lava flows: Meseta de Cali and dissection landforms E of Gobernador Gregores. Early Pliocene (background, top) and Late Pliocene-Pleistocene (left side) basalt flows. The intermediate level corresponds to Miocene gravels of the Pampa de la Compañía Formation (Photo: J-P. Peulvast)

Between the different phases of volcanic activity conducive to paleosurface construction, erosional processes became dominant and, consequently, active dissection and differential erosion led to the partial destruction and topographic inversion of most of the basaltic plateau lavas, whatever be their age. To the west, in the most elevated regions, the most recent flows are frequently inset below the older ones (Fig. 11). Therefore, the various ages and topographic positions of the volcanic paleosurfaces offer good opportunities and further constraints for deciphering the landscape evolution and denudation history of the Deseado region, especially for the Cenozoic times.

\section{Late Cenozoic Sedimentary Paleosurfaces}

The immense flat-lying surfaces corresponding to the "Rodados Patagónicos" (Late Miocene to Pleistocene gravels) as well as the wide terrace systems that are inset at lower levels along the major valleys may themselves be considered as paleosurfaces, since the conditions and processes of their sedimentation have disappeared, probably since the Late Glacial stage. They extend from the Andean piedmont down to the coast (Fig. 12), with a gentle WE regional dip which does not record the intense deformations of the older surface generations (Fig. 13). This piedmont mantle cover, corresponding to poorly consolidated conglomerates rich in 


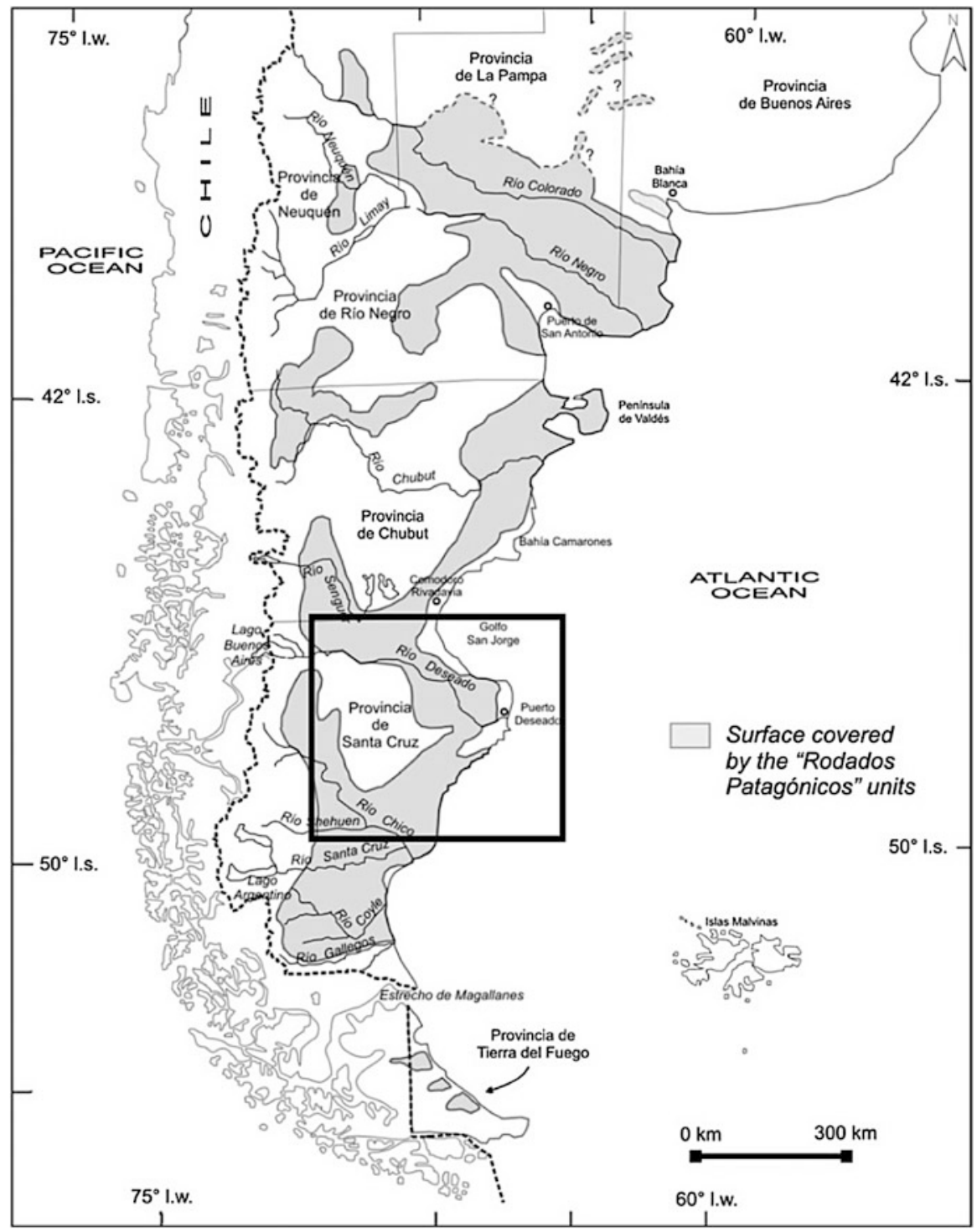

Fig. 12 Geographical distribution of the "Rodados Patagónicos" in southern South America (From Martínez and Kutschker 2011). The rectangle locates the study area

rounded pebbles and gently dipping eastward, would result from the coalescence of alluvial cones in very large fluvial systems (Martínez and Kutschker 2011). While these "Rodados Patagónicos" are likely attributable to the denudation response to accelerated crustal uplift since the Middle Miocene, the nature of the gravel sedimentation is also probably linked to a marked shift towards aridity at that time, 


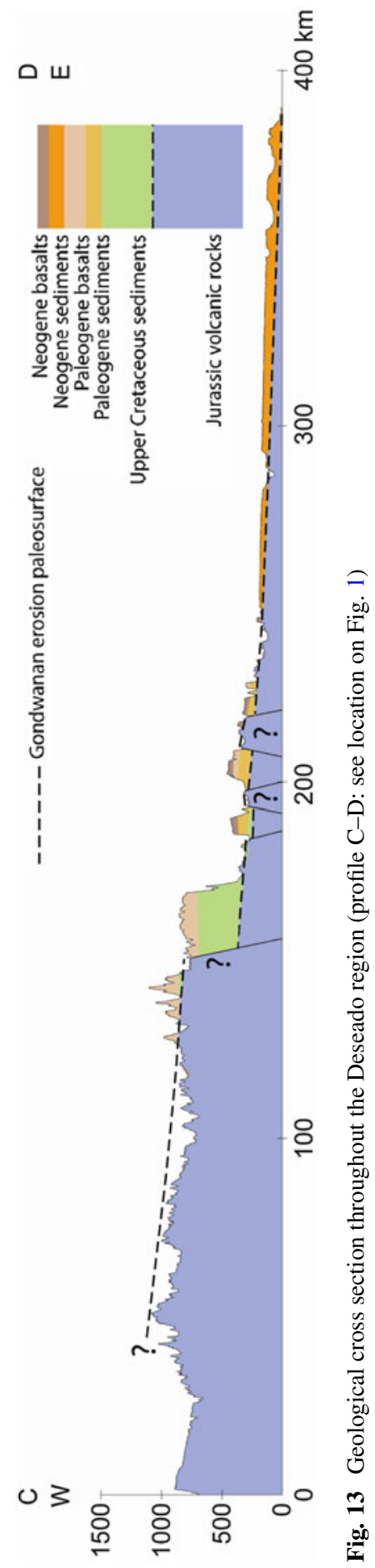


when the culminating uplift of the Andes triggered the appearance of semiarid conditions in southern Patagonia (Iglesias et al. 2011). However, relationships with marginal moraines on the Andean piedmont and faint topographies of braided channels reflect the fluvioglacial conditions of at least a part of their formation, during glacial stages or in terminal stages of the glaciations (outwash plains or sandur; Martínez and Kutschker 2011).

In the west, these deposits form the floor of wide corridors slightly or deeply inset in the higher and older surfaces, around the Deseado and Chico rivers, or even in deep abandoned valleys (EW corridor, east of Gobernador Gregores; Fig. 1), showing that a well-advanced stage of dissection of the plateaus was already achieved or still in progress at the time of their emplacement. To the east, their distal parts were spread unconformably over the Mesozoic to Oligocene-Miocene rocks, onlapping wider and wider tracts of the Gondwana paleosurface, owing to its lower position and its subdued relief. These uniform surfaces, only degraded by closed depressions and shallow valley heads, form a wide continuous fringe along the coast, where low sea cliffs cut the gravel layers and their beveled substrate, as well as the wide terrace systems inset along the major valleys.

\section{Discussion: Implications for Uplift and Denudation Histories}

\section{Geometry of Deformations, Rates, and Causes of Tectonic Uplift}

Geometry and relative amplitude of continental-scale tectonic movements since the end of the Jurassic can be assessed by the deformations recorded by the extensive Gondwana paleosurface. Assuming that the erosion paleosurface was near horizontal in the Late Jurassic, a reconstruction of the paleotopography indicates the geometry of a broad monocline tilted seaward, locally downfaulted, with a maximal differential uplift of $\sim 1,000 \mathrm{~m}$ between the interior highlands and the coastal lowlands (Fig. 1). In a few areas, normal faulting related to extensional tectonics contemporaneous of the oceanic opening has been detected in the vicinity of Cretaceous grabens and small basins (Fig. 13). As a whole, both regional-scale up-doming and flexural deformation seem to have been the dominant style of crustal deformation in the Deseado region in post-Jurassic times.

Local amplitudes and rates of Cenozoic uplift were estimated in the Deseado Massif from the current elevations of Tertiary marine sediments, most of which were deposited in shallow, nearshore environments (Fig. 14). In the "Bosques Petrificados" area, the base of the Salamanca Formation of Paleocene age currently occurs at $\sim 350 \mathrm{~m}$ a.s.l. According to the recalibrated Exxon curve (Miller et al. 2005), ancient sea level was at a maximum of $+50 \mathrm{~m}$ in Paleocene times; so deformation of this stratigraphic marker locally records a Cenozoic crustal uplift of $\sim 300 \mathrm{~m}$, at a mean rate of $5 \mathrm{~m} . \mathrm{Ma}^{-1}$ if averaged over the last 65 Myears, including possible periods of subsidence. In the same area, remnants of younger marine sediments (Monte Leon Formation, dating from Late Oligocene to Early 


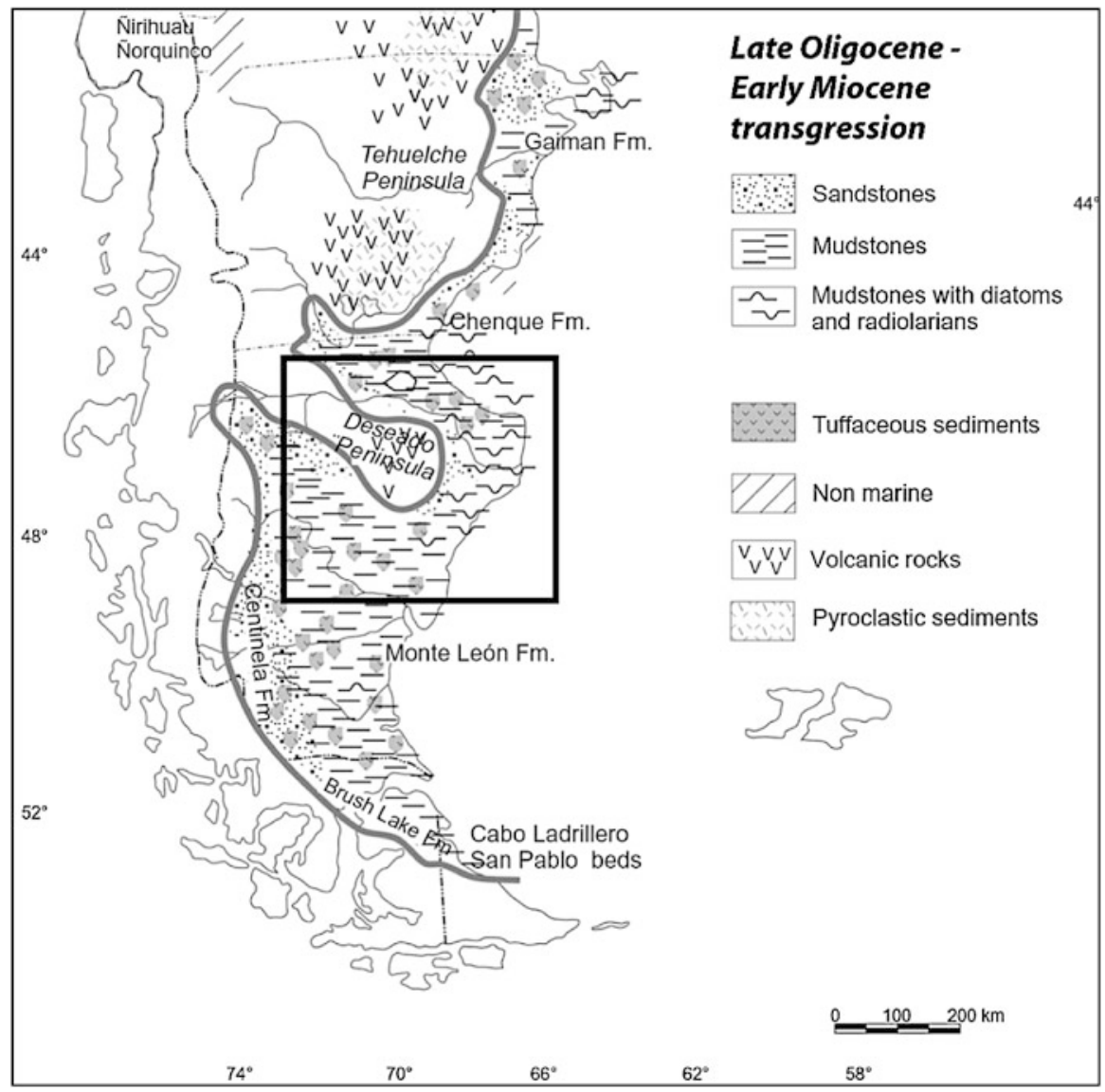

Fig. 14 Paleogeographical reconstruction of the Late Oligocene-Early Miocene transgression (26-20 Ma), responsible for the deposition of the Monte León Formation in the Deseado region (Adapted from Malumián and Náñez 2011). The rectangle locates the study area

Miocene) are found up to $600 \mathrm{~m}$ a.s.l. Assuming that sea level rose from -30 to $+20 \mathrm{~m}$ in Late Oligocene-Early Miocene times (Miller et al. 2005), this indicates a Neogene crustal uplift of $500-600 \mathrm{~m}$, at a rate of $20-25 \mathrm{~m} \cdot \mathrm{Ma}^{-1}$ over the last 25 Myears. In fact, the apparent paradox in the record of uplift by the two sets of sedimentary strata might be explained by the active subsidence of that region until the Early Miocene (Guillaume et al. 2009), that was only recorded by the Paleocene Salamanca formation; it could just as well be due to differentiated vertical movements in different tectonic compartments delineated by normal faults. Anyway, maximal values of Neogene crustal uplift were recorded in the northern part of the Deseado Massif, where the base of the Monte Leon Formation today occurs at $\sim 1,000$ m a.s.l., just below the Pliocene basaltic paleosurface of the Meseta de San Pedro. Such an elevation for the marine sediments indicates a maximal crustal uplift 
of $\sim 1,000 \mathrm{~m}$ for the Neogene, at a mean rate of ca. $40 \mathrm{~m} \cdot \mathrm{Ma}^{-1}$. This estimate is quite similar to the values of post-Middle Miocene uplift calculated from dynamic topography modeling based on mantle-lithosphere interaction (Guillaume et al. 2009). It also confirms the regional-scale south-tilted uplift of the Deseado Massif detected from the geometry of post-Middle Miocene fluvial terraces (Guillaume et al. 2009).

All these data support the idea of an acceleration of tectonic uplift during the Neogene, in probable connection with the Andean convergence and the northward migration of the Chile Triple Junction (Gorring et al. 1997; Guillaume et al. 2009). This migration resulted in the opening of an asthenospheric "slab window"

underneath Southern Patagonia, inducing a disturbance in the regional mantle convection. This slab window notably triggered a new widespread episode of backarc volcanism in southern Patagonia, responsible for the establishment of basaltic plateau and post-plateau lavas in the Deseado region. The dynamic response of the lithosphere resulted in a switch from subsidence to generalized uplift in the Andean foreland that started in the Middle-Late Miocene, when the overall subduction dynamics changed (Guillaume et al. 2009). Dynamic uplift of the Deseado region continued during the Pleistocene, as demonstrated by the deformations recorded by marine terraces along the passive margin of Eastern Patagonia (Pedoja et al. 2011).

\section{Topographic Inversion and Estimation of Denudation Depths and Rates}

During the Cenozoic times, the volcanic province of the Deseado Massif has shown strong evidence of topographic inversion. Uplift and differential erosion resulted in an inversion of topography in places where flood basalts filling paleodepressions and paleovalleys became volcanic mesas or buttes. Estimates of denudation depths and rates on given durations can roughly be inferred from values of topographic inversion observed around Cenozoic volcanic paleosurfaces in different places of the Deseado Massif. A mean estimation of Cenozoic denudation rates can be obtained from the values of topographic inversion of Paleogene volcanic paleosurfaces. Maximum values of denudation depths are found in the central part of the Deseado Massif, where topographic inversion of Paleocene to Oligocene basaltic mesas reached $200-500 \mathrm{~m}$. In all cases, the corresponding mean denudation rates are $<10 \mathrm{~m} \cdot \mathrm{Ma}^{-1}$ (most often $<4-5 \mathrm{~m} \cdot \mathrm{Ma}^{-1}$ ). Such low denudation rates for the Cenozoic are similar to those of vertical tectonic movements deduced from the altitudes of Paleocene marine strata. The same procedure can be applied from the values of topographic inversion of Neogene volcanic paleosurfaces. Maximum post-Miocene denudation depths are provided by the maximum value of topographic inversion observed around the Meseta de San Pedro, in the northern part of the Deseado Massif, i.e., $\sim 800 \mathrm{~m}$ since $5 \mathrm{Ma}$. Close values of denudation depths are found in the central part of the massif, east of the "Bosques Petrificados" area, around Miocene basaltic mesas ( $\sim 750 \mathrm{~m}$ since $15 \mathrm{Ma})$. In the last area, lower values of denudation 
depths are observed below Pliocene-Pleistocene basaltic plateau remnants, but the inversion occurred on shorter durations, also indicating mean denudation rates of 40-50 m. $\mathrm{Ma}^{-1}$ since the Miocene or later.

This set of data suggests an acceleration of denudation during the Neogene locally as high as $160 \mathrm{~m} . \mathrm{Ma}^{-1}$, as it has been observed in the northern part of the massif, around the Meseta de San Pedro. This perfectly matches the observations made on uplift rates accelerating during the Neogene (see above), especially in postMiddle Miocene times when started the generalized uplift of the Andean foreland in connection with ridge collision at the Chile Triple Junction (Guillaume et al. 2009). The sedimentary record of denudation for that period is contained in the Neogene continental deposits and piedmont mantle covers accumulated in the coastal lowlands, suggesting a definitive shift of depositional centers to the new Atlantic Ocean margin associated to an increasingly buoyant and eroding hinterland. Following the deposition of the marine and continental series of Late Oligocene-Early Miocene age (Monte Leon and Santa Cruz formations), the widespread accumulation of the Late Cenozoic "Rodados Patagónicos" (Martínez and Kutschker 2011) has taken place since the Middle-Late Miocene, in response to tectonic and/or climatic forcing. The fluvial terrace levels inset below the accumulation surface of the Late Cenozoic piedmont mantle cover results from the fluvial and fluvioglacial activity of rivers flowing from the Andes to the Atlantic Ocean, in the context of glacialinterglacial periods of the Pliocene-Pleistocene and glacio-eustatic fluctuations.

The presence of so many markers of the geomorphic, sedimentary, and tectonic history, and the well constrained reconstruction of a subsidence stage followed by uplift and relief inversion would make this region an ideal example for discussing the pertinence and the possible mechanisms of the controversial "episodic burial and exhumation model" recently advocated by some authors in other parts of the eastern margin of South America (Northeast Brazil: Japsen et al. 2012). Built on the basis of thermochronological analyses, and of extrapolations from scattered morphostratigraphic evidence, this model implies values and long-term rates of sedimentation and denudation, up to $200 \mathrm{~m} \cdot \mathrm{Ma}^{-1}$ in the Eocene and $150 \mathrm{~m} \cdot \mathrm{Ma}^{-1}$ since the Miocene, well beyond those generally observed in the Deseado region, in spite of a more stable tectonic environment, far from the Andes. Accompanied by thermochronological studies (fission track and U-Th/He on apatites), such a comparison would also permit a discussion of the calibration of these methods which often give results showing strong discrepancies with morphostratigraphic evidence (Peulvast et al. 2009; Ricordel-Prognon et al. 2010).

\section{Conclusions and Perspectives}

The current landscape of the Deseado Massif reflects a juxtaposition of stepped surfaces which correspond to paleolandforms and paleolandscapes of various types and ages, identified by the means of a morphostratigraphic analysis. Therefore, this preliminary study leads to original results concerning the long-term land- 
scape development of this large platform area and volcanic province of Southern Patagonia. From the Late Jurassic to the Early Tertiary, the Deseado Massif has shown evidence of long-term geomorphological stability, as demonstrated by the good preservation of the Gondwana (Late Jurassic-Early Cretaceous) erosion paleosurface. This paleotopography, irregularly altered and/or weathered by kaolinization, was progressively buried below various thicknesses of Cretaceous-Tertiary sediments and basaltic lava flows, in a context of regional subsidence or relative tectonic quiescence. However, a generalized uplift occurring in the Neogene resulted in the topographic inversion of Cenozoic volcanic plateau lavas, the exhumation of buried paleosurfaces/stratigraphic unconformities, and the dissection of the regional landforms. All our data suggest an acceleration of uplift and denudation since the Miocene, in response to the tectonic forcing induced by changes in the Andean subduction dynamics at the time. The exact timing and causes of denudation history during Meso-Cenozoic times are still poorly constrained. The identification of other erosion paleosurfaces with their associated weathering signatures, and the detailed investigation of offshore sedimentary data, should help in deciphering the complex erosional history of that region. Because of the exploratory nature of this study, and of the lack of data on key problems such as the precise age of some volcanic formations and sedimentary deposits, many issues of long-term landscape evolution are not solved and consequently need further investigations.

\section{References}

Aguilera EY, Rabassa J (2010) Origin of the northern Patagonian massif regional paleosurface. Geociências 29(4):467-478. São Paulo, UNESP

Aguilera EY, Rabassa J, Imbelloni P (2012) Paleosuperficie de meteorización en el Macizo del Deseado. V Congreso Argentino de Geomorfología y Cuaternario, Abstracts. Río Cuarto, Córdoba

Andreis RR (2002a) Cuenca La Golondrina (depósitos del rift Pérmico y eventos magmáticos triásicos). In: Haller MJ (ed) Geología y Recursos Naturales de Santa Cruz, Relatorio, $15^{\circ}$ Congreso Geológico Argentino, El Calafate, Buenos Aires, pp 71-82

Andreis RR (2002b) Cuenca Baqueró - secuencia volcaniclástica eocretácica del Macizo del Deseado. In: Haller MJ (ed) Geología y Recursos Naturales de Santa Cruz, Relatorio, $15^{\circ}$ Congreso Geológico Argentino, El Calafate, Buenos Aires, pp 149-164

Bétard F (2010) Uplift and denudation history at low-elevation passive margins: insights from morphostratigraphic analysis in the SE Armorican Massif along the French Atlantic margin. C R Geosci 342:215-222

Blisniuk PM, Stern LA, Chamberlain CP, Idleman B, Zeitler PK (2005) Climatic and ecologic changes during Miocene surface uplift in the southern Patagonian Andes. Earth Planet Sci Lett 230:125-142

Calvet M, Gunnell Y (2008) Planar landforms as markers of denudation chronology: an inversion of East Pyrenean tectonics based on landscape and sedimentary basin analysis. In: Gallagher $\mathrm{K}$, Jones SJ, Wainwright $\mathrm{J}$ (eds) Landscape evolution: denudation, climate and tectonics over different time and space scales, Special publications 296. Geological Society, London, pp 147-166 
Carignano C, Cioccale M, Rabassa J (1999) Landscape antiquity of the Central-Eastern Sierras Pampeanas (Argentina): geomorphological evolution since Gondwanic times. Z. Geomorph. N.F., Suppl.-Bd 118:245-268

Cavallotto JL, Violante RA, Hernández-Molina FJ (2011) Geological aspects and evolution of the Patagonian continental margin. Biol J Linn Soc 103:346-362

Cravero MF, Domínguez EA (1992) Kaolin deposits in the Lower Cretaceous Baqueró Formation (Santa Cruz province, Patagonia, Argentina). J S Am Earth Sci 6(4):223-235

Darwin C (1842) On the distribution of the erratic boulders and on the contemporaneous unstratified deposits of South America. Trans Geol Soc Lond 6:415-431

de Barrio RE (1989) Aspectos geológicos y geoquímicos de la Formación Chon Aike (Grupo Bahía Laura) en el noroeste de la provincia de Santa Cruz. Unpublished doctoral thesis, Facultad de Ciencias Naturales y Museo, Universidad Nacional de La Plata, La Plata, 175 pp

De Giusto JM, Di Persia CA, Pezzi E (1980) Nesocratón del Deseado. In: Turner JC (coord.) Geología Regional Argentina, vol 2. Academia Nacional de Ciencias, Córdoba, pp 1389-1430

Demoulin A, Zárate M, Rabassa J (2005) Long-term landscape development: a perspective from the southern Buenos Aires ranges of east central Argentina. J S Am Earth Sci 19:193-204

Dumont P (1991) Problèmes de datation des surfaces d'aplanissement au Zaïre. Bulletin de la Société géographique de Liège 27:175-185

Echavarría LE, Schalamuk IB, Etcheverry RO (2005) Geologic and tectonic setting of Deseado Massif epithermal deposits, Argentina, based on El Dorado-Monserrat. J S Am Earth Sci 19:415-432

Fidalgo F, Riggi JC (1965) Los rodados patagónicos en la Meseta del Guenguel y alrededores (provincia de Santa Cruz). Revista Asociación Geológica Argentina 20(3):430-443

Fidalgo F, Riggi JC (1970) Consideraciones geomórficas y sedimentológicas sobre los Rodados Patagónicos. Revista Asociación Geológica Argentina 25(4):272-325

Giacosa RE, Márquez M, Panza JL (2002) Basamento Paleozoico inferior del Macizo del Deseado. In: Haller MJ (ed) Geología y Recursos Naturales de Santa Cruz, Relatorio, $15^{\circ}$ Congreso Geológico Argentino, El Calafate, Buenos Aires, pp 33-44

Giacosa R, Zubia M, Sánchez M, Allard J (2010) Meso-Cenozoic tectonics of the southern Patagonian foreland: structural evolution and implications for $\mathrm{Au}-\mathrm{Ag}$ veins in the eastern Deseado Region (Santa Cruz, Argentina). J S Am Earth Sci 30:134-150

Godard A, Lagasquie JJ, Lageat Y (eds) (2001) Basement regions. Springer, Berlin/Heidelberg/New York, $306 \mathrm{p}$

Gorring ML, Kay SM, Zeitler PK, Ramos VA, Rubiolo D, Fernández I, Panza JL (1997) Neogene Patagonian plateau lavas: continental magmas associated with ridge collision at the Chile triple junction. Tectonics 16:1-17

Gorring ML, Singer B, Gowers J, Kay SM (2003) Plio-Pleistocene basalts from the Meseta del Lago Buenos Aires, Argentina: evidence for asthenosphere-lithosphere interactions during slab window magmatism. Chem Geol 193:215-235

Guido DM, Campbell KA (2011) Jurassic hot spring deposits of the Deseado Massif (Patagonia, Argentina): characteristics and controls on regional distribution. J Volcanol Geoth Res 203:35-47

Guido DM, Campbell KA (2012) Diverse subaerial and sublacustrine hot spring settings of the Cerro Negro epithermal system (Jurassic, Deseado Massif), Patagonia, Argentina. J Volcanol Geoth Res 229-230:1-12

Guido DM, Escayola MP, Schalamuk IB (2004) The basement of the Deseado Massif at Bahía Laura, Patagonia, Argentina: a proposal for its evolution. J S Am Earth Sci 16:567-577

Guillaume B, Martinod J, Husson L, Roddaz M, Riquelme R (2009) Neogene uplift of central eastern Patagonia: dynamic response to active spreading ridge subduction? Tectonics 28, TC2009. doi:10.1029/2008TC002324

Gunnell Y (2003) Radiometric ages of laterites and constraints on long-term denudation rates in West Africa. Geology 31(2):131-134 
Haller MJ (2002) La Cuenca Triásica de El Tranquilo. In: Haller MJ (ed) Geología y Recursos Naturales de Santa Cruz, Relatorio, $15^{\circ}$ Congreso Geológico Argentino, El Calafate, Buenos Aires, pp 83-86

Homove JF, Constantini LA (2001) Hydrocarbon exploration potential within intraplate shearrelated depocenters Deseado and San Julián Basins, Southern Argentina. AAPG Bull 85: $1795-1815$

Iglesias A, Artabe AE, Morel EM (2011) The evolution of Patagonian climate and vegetation from the Mesozoic to the present. Biol J Linn Soc 103:409-422

Japsen P, Bonow J, Green P, Chalmers JA, Lidmar-Bergström K (2009) Formation, uplift and dissection of planation surfaces at passive continental margins - a new approach. Earth Surf Process Landforms 34(5):683-699

Japsen P, Bonow JM, Green PF, Cobbold PR, Chiossi D, Lilletveit R, Magnavita LP, Pedreira A (2012) Episodic burial and exhumation in NE Brazil after opening of the South Atlantic. Geol Soc Am Bull 124(5-6):800-816

Klein C (1997) Du polycyclisme à l'acyclisme en géomorphologie. Ophrys, Gap, 299 p

Lageat Y, Robb LJ (1984) The relationships between structural landforms, erosion surfaces and the geology of the Archean granite basement in the Barberton region, Eastern Transvaal. Trans Geol Soc S Afr 87:141-159

Lidmar-Bergström K, Bonow JM, Japsen P (2013) Stratigraphic Landscape Analysis and geomorphological paradigms: Scandinavia as an example of Phanerozoic uplift and subsidence. Glob Planet Change 100:153-171

Malumián N (2002) El Terciario marino: sus relaciones con el eustatismo. In: Haller MJ (ed) Geología y Recursos Naturales de Santa Cruz, Relatorio, $15^{\circ}$ Congreso Geológico Argentino, El Calafate, Buenos Aires, pp 237-244

Malumián M, Náñez C (2011) The Late Cretaceous-Cenozoic transgressions in Patagonia and the Fuegian Andes: foraminifera, palaeoecology, and palaeogeography. Biol J Linn Soc 103: 269-288

Márquez MJ, Giacosa RE, Godeas M (2002) Los granitoides gondwánicos del borde oriental del Macizo del Deseado. In: Haller MJ (ed) Geología y Recursos Naturales de Santa Cruz, Relatorio, $15^{\circ}$ Congreso Geológico Argentino, El Calafate, Buenos Aires, pp 57-70

Martínez OA, Kutschker A (2011) The 'Rodados Patagónicos' (Patagonian Shingle Formation) of eastern Patagonia: environmental conditions of gravel sedimentation. Biol J Linn Soc 103: 336-345

Miller KG, Kominz MA, Browning JV, Wright JD, Mountain GS, Katz ME et al (2005) The Phanerozoic record of global sea-level change. Science 310:1293-1298

Nahon D (2003) Altérations dans la zone tropicale. Signification à travers les mécanismes anciens et/ou encore actuels. C R Geosci 335:1109-1119

Nullo F, Combina A (2002) Sedimentitas terciarias continentales. In: Haller MJ (ed) Geología y Recursos Naturales de Santa Cruz, Relatorio, $15^{\circ}$ Congreso Geológico Argentino, El Calafate, Buenos Aires, pp 245-258

Nullo F, Combina A (2011) Patagonian continental deposits (Cretaceous-Tertiary). Biol J Linn Soc 103:289-304

Ollier C (1991) Ancient landforms. Belhaven Press, London, 233 p

Panza J, Franchi M (2002) Magmatismo Basáltico Cenozoico Extraandino. In: Haller MJ (ed) Geología y Recursos Naturales de Santa Cruz. Relatorio, $15^{\circ}$ Congreso Geológico Argentino, El Calafate, Buenos Aires, pp 259-284

Panza JL, Haller MJ (2002) El volcanismo jurásico. In: Haller MJ (ed) Geología y Recursos Naturales de Santa Cruz, Relatorio, $15^{\circ}$ Congreso Geológico Argentino, El Calafate, Buenos Aires, pp 89-102

Panza JL, Sacomani E, Cobos JC (2003) Mapa Geológico de la Provincia de Santa Cruz, escala 1:750.000. Programa Nacional de Cartas Geológicas, SEGEMAR, Buenos Aires

Partridge T, Maud RR (1987) Geomorphic evolution of Southern Africa since the Mesozoic. S Afr J Geol 90:179-208 
Pedoja K, Regard V, Husson L, Martinod J, Guillaume B, Fucks E, Iglesias M, Weill P (2011) Uplift of Quaternary shorelines in eastern Patagonia: Darwin revisited. Geomorphology 127:121-142

Peulvast J-P, Claudino Sales V (2004) Stepped surfaces and palaeolandforms in the northern Brazilian "Nordeste": constraints on models of morphotectonic evolution. Geomorphology 62:89-122

Peulvast J-P, Claudino Sales V (2005) Surfaces d'aplanissement et géodynamique. Géomorphol Relief Processus Environ 4:249-274

Peulvast J-P, Vanney JR (2001) Géomorphologie structurale (Terre, corps planétaires solides), vol 1: Relief et structure. Gordon \& Breach (Paris) and BRGM (Orléans), $505 \mathrm{p}$

Peulvast J-P, Bouchard M, Jolicoeur S, Pierre G, Schroeder J (1996) Palaeotopographies and post-orogenic morphotectonic evolution around the Baie des Chaleurs (Eastern Canada). Geomorphology 16:5-32

Peulvast J-P, Claudino Sales V, Bétard F, Gunnell Y (2008) Low post-Cenomanian denudation depths across the Brazilian Northeast: implications for long-term landscape evolution at a transform continental margin. Glob Planet Change 62:39-60

Peulvast J-P, Bétard F, Lageat Y (2009) Long-term landscape evolution and denudation rates in shield and platform areas: a morphostratigraphic approach. Géomorphol Relief Processus Environ 2:95-108

Rabassa J (2010) Gondwana paleolandscapes: long-term landscape evolution, genesis, distribution and age. Geociências 29(4):541-570. São Paulo, UNESP

Rabassa J, Zárate M, Cioccale M, Carignano C, Partridge TC, Maud R (1996) Paisajes relictuales de edad Gondwánica en áreas cratónicas de Argentina. XIII Congreso Geológico Argentino and III Congreso de Exploración de Hidrocarburos, Actas, 4, Buenos Aires, p 219

Rabassa J, Carignano C, Cioccale M (2010) Gondwana paleosurfaces in Argentina: an introduction. Geociências 29(4):439-466. São Paulo, UNESP

Rabassa J, Carignano C, Cioccale M (2014) A general overview of Gondwana landscapes in Argentina. In: Rabassa J, Ollier C (eds) Gondwana landscapes in southern South America. Springer, Dordrecht, pp 201-245

Ricordel-Prognon C, Lagroix F, Moreau MG, Thiry M (2010) Lateritic paleoweathering profiles in French Massif Central: paleomagnetic datings. J Geophys Res 115:B10104. doi:10.1029/2010JB007419

Summerfield MA, Sugden DE, Denton GH, Marchant DR, Cockburn HAP, Stuart FM (1999) Cosmogenic isotope data support previous evidence of extremely low rates of denudation in the Dry Valleys region, southern Victoria Land, Antarctica. Geol Soc Spec Publ 162:255-267

Thomas MF (1994) Geomorphology in the tropics: a study of weathering and denudation in low latitudes. Wiley, Chichester/New York, $482 \mathrm{p}$

Vasconcelos PM, Conroy M (2003) Geochronology of weathering and landscape evolution, Dugald River valley, NW Queensland, Australia. Geochimica et Cosmochimica Acta 67:2913-2930

Watchman AL, Twidale CR (2002) Relative and "absolute" dating of land surfaces. Earth Sci Rev 58:1-49

Widdowson M (1997) The geomorphological and geological importance of paleosurfaces. In: Widdowson M (ed) Paleosurfaces: recognition, reconstruction and paleoenvironmental interpretation, Special publication 120. Geological Society of London, London, pp 1-12 